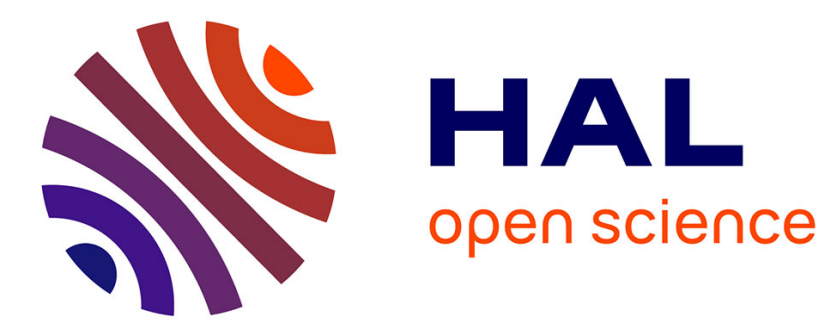

\title{
Structural Changes in the Perovskitic Compounds Series Sr2Mg1-xMIIxMoO6
}

\author{
M. Craus, M. Palamaru, A. Cecal, I. Rusu, A. Iordan
}

\section{To cite this version:}

M. Craus, M. Palamaru, A. Cecal, I. Rusu, A. Iordan. Structural Changes in the Perovskitic Compounds Series Sr2Mg1-xMIIxMoO6. Journal de Physique IV Proceedings, 1997, 07 (C1), pp.C1-375C1-376. 10.1051/jp4:19971154 . jpa-00254799

\section{HAL Id: jpa-00254799 https://hal.science/jpa-00254799}

Submitted on 1 Jan 1997

HAL is a multi-disciplinary open access archive for the deposit and dissemination of scientific research documents, whether they are published or not. The documents may come from teaching and research institutions in France or abroad, or from public or private research centers.
L'archive ouverte pluridisciplinaire HAL, est destinée au dépôt et à la diffusion de documents scientifiques de niveau recherche, publiés ou non, émanant des établissements d'enseignement et de recherche français ou étrangers, des laboratoires publics ou privés. 


\title{
Structural Changes in the Perovskitic Compounds Series $\mathrm{Sr}_{2} \mathrm{Mg}_{1-x} \mathrm{M}^{\mathrm{II}}{ }_{x} \mathrm{MoO}_{6}$
}

\author{
M.L. Craus, M.N. Palamaru*, A. Cecal*, I. Rusu** and A.R. Iordan* \\ Institute of Technical Physics, Bd. D. Mangeron nr. 47, 6600 Iasi, Romania \\ * University "Al. I. Cuza", Faculty of Chemistry, Bd. Copou nr. 11, 6600 Iasi, Romania \\ ** University "Gh. Asachi", Faculty of Industrial Chemistry, 6600 Iasi, Romania
}

\begin{abstract}
Two series of perovskite type compounds (Sr2Mg1-xZnxMoO6 and Sr2Mg1-xNixMoO6) are characterized from the structural point of view. The synthesis conditions are briefly described. The cation distribution of the two series compounds were determined by $\mathrm{X}$-ray diffraction.
\end{abstract}

The synthesis of $\mathrm{A}_{2} \mathrm{BB}^{\prime} \mathrm{O}_{6}$ perovskites $\left(A=\mathrm{Sr} ; \mathrm{B}=\mathrm{W}, \mathrm{Mo} ; \mathrm{B}^{\prime}=\mathrm{Ni}, \mathrm{Co}, \mathrm{Zn}\right.$ ) allowed to obtain compounds with a tetragonal structure, $a$ and $b$ parameters taking values between 5.561 and $5.596 \AA$ and $c$ between 7.886 and $7.978 \AA$ [1, 2]. Palamaru et al $[3,4]$ obtained $\mathrm{Sr}_{2} \mathrm{MgMoO}_{6}$ starting from the following materials $\mathrm{SrMoO}_{4}, \mathrm{MgC}_{2} \mathrm{O}_{4}, 2 \mathrm{H}_{2} \mathrm{O}, \mathrm{Mg}(\mathrm{OH})_{2}$ and $\mathrm{Sr}(\mathrm{NO} 3)_{2}$. The perovskite has a nearly cubic structure $(a=b=7.879, c=7.928 \AA$ ). We meant to synthesize by similar methods, $\mathrm{Sr}_{2} \mathrm{Mg}_{1-\mathrm{x}^{\mathrm{M}}} \mathrm{II}_{\mathrm{x}} \mathrm{MoO}_{6}$ type oxides $\left(\mathrm{M}^{\mathrm{II}}=\mathrm{Ni}, \mathrm{Zn}\right)$, for their potential to be used as supports for HTSC.

Table 1. Cation distribution of the system $\mathrm{Sr}_{2} \mathrm{Mg}_{\mathrm{x}} \mathrm{Zn}_{1-\mathrm{x}} \mathrm{MoO}_{6}$ (I - W type site ; II - Ni type site [5])

\begin{tabular}{|c|c|c|c|c|c|}
\hline Composition & $I_{220+202}$ & $I_{311+113}$ & $I_{222}$ & $I_{400+004}$ & Observations \\
\hline $\mathrm{Sr}_{2}(\mathrm{Mg})_{1}(\mathrm{Mo})_{11} \mathrm{O}_{6}{ }^{*}$ & 100 & 9.8 & 10.1 & 35.7 & Calculated intensities \\
\hline $\mathrm{Sr}_{2} \mathrm{MgMoO}_{6}{ }^{* *}$ & 100 & 8.3 & 15,6 & 36.5 & Observed intensities \\
\hline $\mathrm{Sr}_{2}\left(\mathrm{Mg}_{025} \mathrm{Zn}_{02} \mathrm{Mo}_{0}\right){ }_{1}\left(\mathrm{Mg}_{0} \mathrm{Mo}_{0}\right)_{1 \mathrm{O}} \mathrm{O}_{6}{ }^{*}$ & 100 & $\overrightarrow{0.9}$ & 12.2 & 36.7 & Calculated intensities \\
\hline $\mathrm{Sr}_{2} \mathrm{Mg}_{0.75} \mathrm{Zn}_{0.25} \mathrm{MoO}_{6}^{* *}$ & 100 & 0.0 & 10.0 & 38.7 & Observed intensities \\
\hline $\mathrm{Sr}_{2}\left(\mathrm{Mg}_{0.5} \mathrm{Zn}_{0.5}\right)_{\mathrm{I}}\left(\mathrm{Mg}_{0.5} \mathrm{Mo}_{0.5}\right)_{\mathrm{II}} \mathrm{O}_{6}^{*}$ & $\overline{100}$ & 0.7 & 5.6 & 32.4 & Calculated intensities \\
\hline $\mathrm{Sr}_{2} \mathrm{Mg}_{0.5} \mathrm{Zn}_{0.5} \mathrm{MoO}_{6}{ }^{* *}$ & 100 & 3.7 & 7.4 & 42.2 & Observed intensities \\
\hline $\mathrm{Sr}_{2}\left(\mathrm{Mg}_{0.25} \mathrm{Zn}_{0.75}\right)\left(\mathrm{Mg}_{0.25} \mathrm{Mo}_{0.75}\right)_{1 \mathrm{O}} \mathrm{O}_{6}{ }^{*}$ & 100 & 1.0 & 12.3 & 35.0 & Calculated intensities \\
\hline $\mathrm{Sr}_{2} \mathrm{Mg}_{0.25} \mathrm{Zn}_{0.75} \mathrm{MoO}_{6}{ }^{* *}$ & 100 & 2.3 & 9.2 & 39.2 & Observed intensities \\
\hline $\mathrm{Sr}_{2}\left(\mathrm{Zn}_{0.5} \mathrm{Mo}_{0.5}\right)_{\mathrm{T}}\left(\mathrm{Zn}_{0.5} \mathrm{Mo}_{0.5}\right)_{\mathrm{II}^{\mathrm{O}}}{ }_{6}{ }^{*}$ & 100 & 0.7 & 5.6 & 32.4 & Calculated intensities \\
\hline $\mathrm{Sr}_{2} \mathrm{ZnMOO}_{6} * *$ & 100 & 0.0 & 5.9 & 37.0 & Observed intensities \\
\hline
\end{tabular}

*:Calculated cation distribution ; **: Nominal composition

The samples were obtained by the ceramic method using as starting materials high purity $\mathrm{SrMoO} 4, \mathrm{Sr}\left(\mathrm{NO}_{3}\right)_{2}, \mathrm{MgO}, \mathrm{NiO}$ and $\mathrm{ZnO}$. The pre sintering was performed in air at $700^{\circ} \mathrm{C}$ and $850^{\circ} \mathrm{C} / 1-1.5 \mathrm{~h}$, depending the $\mathrm{M}^{\mathrm{II}}$ cation type. The samples were ground for $10 \mathrm{~h}$, pressed into pellets and heated in air at 1150 and $1250^{\circ} \mathrm{C}$ for $3-5 \mathrm{~h}$. The crude, presintered and sintered samples were characterized chemically, metalographically and by $\mathrm{X}$-ray diffraction. The theoretical intensities of the diffraction peaks were calculated using equation (1), and the cation distribution was tested using equation (2), [6]. For lower annealing temperatures an intermediate compound was evidenced. For these samples, the lower the $\mathrm{MgO}$ concentration the lower the intermediate compound concentration. The samples annealed at $1150^{\circ} \mathrm{C}$ contain a mixture of $\mathrm{Sr}_{2} \mathrm{Mg}_{1-\mathrm{x}} \mathrm{M}^{\mathrm{II}} \mathrm{MoO}_{6}$ (the outstanding phase) and (Mg, $\left.\mathrm{M}^{\amalg}\right) \mathrm{O}$. The phases were identified using ASTM file cards 15-601 and 4-835. Higher annealing temperatures $\left(1280^{\circ} \mathrm{C}\right.$ in air) led to the decomposition of the main phase with the appearance of $\mathrm{SrMoO} 4 . \mathrm{X}-\mathrm{ray}$ measurements allowed the determination of the most probable cation distribution both for the system $\mathrm{Sr}_{2} \mathrm{Mg}_{\mathrm{x}} \mathrm{Zn}_{1-\mathrm{x}} \mathrm{MoO}_{6}$ (Table 1) and for the system $\mathrm{Sr}_{2} \mathrm{Mg}_{\mathrm{X}} \mathrm{Ni}_{14 \mathrm{x}} \mathrm{MoO}_{6}$ (Table 2). In the system $\mathrm{Sr}_{2} \mathrm{Mg}_{\mathrm{X}} \mathrm{Zn}_{1-\mathrm{x}} \mathrm{MoO}_{6}$ the magnesium cations are 
disposed both on the middle of the edges and in the center of the unit cell, and on the corners and on the center of the unit cell faces, excepting the sample that contains only magnesium. In this case the magnesium seems to be placed on the corners and on the center of the unit cell faces.

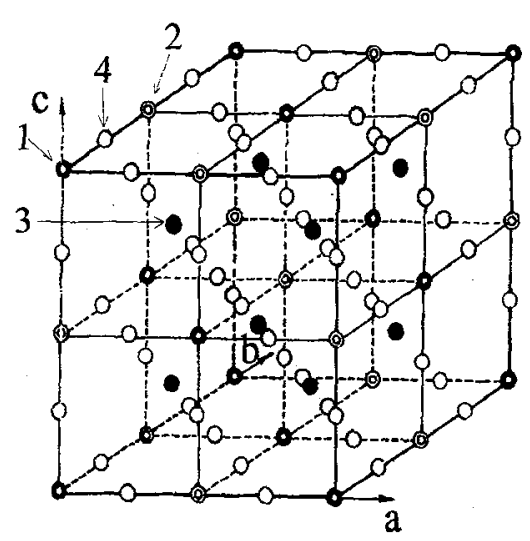

Fig.1. The proposed structure for $\mathrm{Sr}_{2} \mathrm{MgMoO}_{6}$ (1) W type sites; (2) Ni types sites [5]; (3) $\mathrm{Sr}$; (4) O. W $\rightarrow$ Mo (Mg, Ni, Zn); Ni $\rightarrow \mathrm{Mg}(\mathrm{Ni}, \mathrm{Mo}, \mathrm{Zn})$.

$$
\begin{aligned}
& I_{h k l}=k p|F(h k l)|^{2} A \frac{1+\cos ^{2} 2 \theta}{\cos ^{2} \theta \sin \theta} \exp \left(-2 B\left(\frac{\sin \theta}{\lambda}\right)^{2}\right)=k_{h k l} \\
& \sum_{h, k, l}\left|\frac{R_{h k l, e x p}-R_{h k l, c a l c}}{R_{h k l, c a l c}}\right|=\min
\end{aligned}
$$

The zinc cations are generally placed on the $W$ type sites, excepting for the $\mathrm{Sr}_{2} \mathrm{ZnMOO}_{6}$ sample where they are placed on Ni type sites [5]. The cation distribution for $\mathrm{Sr}_{2} \mathrm{MgMoO}_{6}$ is in agreement with those obtained in our previous paper [3, 4]. Analyzing the theoretical data for the cation distribution, in the system $\mathrm{Sr}_{2} \mathrm{Mg}_{\mathrm{x}} \mathrm{Ni}_{1-\mathrm{x}} \mathrm{MoO}_{6}$, one can be noticed that the magnesium ions are placed both on the $\mathrm{Ni}$ and $\mathrm{W}$ sites in the $\mathrm{Sr}_{2} \mathrm{NiWO}_{6}$ compound. There is no a preferential ordering neither for magnesium nor for nickel ions, may be because their ionic radii are almost identical. The cation ordering is influenced both by the temperature and by the chemical composition.

Because the W type sites[5] corresponding to the octahedral places have a smaller volume than that of the $\mathrm{Ni}$ type sites, the $\mathrm{Mg} / \mathrm{Ni}$ energy of interaction with the oxygen ions is stronger in the first case than in the second.

\begin{tabular}{|c|c|c|c|c|c|c|}
\hline Composition & $I_{111}$ & $\mathrm{I}_{220+202}$ & $I_{311+113}$ & $I_{222}$ & $I_{400+004}$ & Observations \\
\hline $\begin{array}{l}\mathrm{Sr}_{2}\left(\mathrm{Mg}_{0.2} \mathrm{Ni}_{0.8}\right)\left(\mathrm{Mo}_{1 \mathrm{r}} \mathrm{O}_{6}{ }^{*}\right. \\
\mathrm{Sr}_{2} \mathrm{Mg}_{0.2} \mathrm{Ni}_{0.8} \mathrm{MoO}_{6}{ }^{* *}\end{array}$ & $\begin{array}{c}4.5 \\
24.4 \\
\end{array}$ & $\begin{array}{l}100 \\
100 \\
\end{array}$ & $\begin{array}{l}2.5 \\
6.7 \\
\end{array}$ & $\begin{array}{c}4.7 \\
11.7 \\
\end{array}$ & $\begin{array}{l}33.3 \\
28.9 \\
\end{array}$ & $\begin{array}{l}\text { Calculated intensities } \\
\text { Observed intensities }\end{array}$ \\
\hline $\begin{array}{l}\mathrm{Sr}_{2}(\mathrm{Mo})_{\mathrm{T}}\left(\mathrm{Mg}_{0.4} \mathrm{Ni}_{0.6}\right) \mathrm{HI}_{6} \mathrm{O}{ }^{*} \\
\mathrm{Sr}_{2} \mathrm{MoMg}_{0.4} \mathrm{Ni}_{0.6} \mathrm{O}_{6}{ }^{* *}\end{array}$ & $\begin{array}{r}8.0 \\
24.4 \\
\end{array}$ & $\begin{array}{l}100 \\
100 \\
\end{array}$ & $\begin{array}{l}4.3 \\
6.7 \\
\end{array}$ & $\begin{array}{c}6.3 \\
11.7 \\
\end{array}$ & $\begin{array}{l}34.1 \\
35.5 \\
\end{array}$ & $\begin{array}{l}\text { Calculated intensities } \\
\text { Observed intensities }\end{array}$ \\
\hline $\begin{array}{l}\mathrm{Sr}_{2}(\mathrm{Mo})_{1}\left(\mathrm{Mg}_{0.6} \mathrm{Ni}_{0.4}\right)_{11} \mathrm{O}_{6}{ }^{*} \\
\mathrm{Sr}_{2} \mathrm{Mg}_{0.6} \mathrm{Ni}_{0.4} \mathrm{MoO}_{6}^{* *}\end{array}$ & $\begin{array}{l}13.1 \\
21.1 \\
\end{array}$ & $\begin{array}{l}100 \\
100 \\
\end{array}$ & $\begin{array}{l}6.9 \\
7.5 \\
\end{array}$ & $\begin{array}{r}8.2 \\
12.8 \\
\end{array}$ & $\begin{array}{l}34.9 \\
39.2 \\
\end{array}$ & $\begin{array}{l}\text { Calculated intensities } \\
\text { Observed intensities }\end{array}$ \\
\hline $\begin{array}{l}\mathrm{Sr}_{2}\left(\mathrm{Mg}_{0.8} \mathrm{Ni}_{0.2}\right)_{\mathrm{I}}(\mathrm{Mo})_{1 \mathrm{I}} \mathrm{O}_{6}{ }^{*} \\
\mathrm{Sr}_{2} \mathrm{Mg}_{0.8} \mathrm{Ni}_{0.2} \mathrm{MoO}_{6}{ }^{* *}\end{array}$ & $\begin{array}{c}1.3 \\
10.7 \\
\end{array}$ & $\begin{array}{l}100 \\
100 \\
\end{array}$ & $\begin{array}{l}1.0 \\
3.2 \\
\end{array}$ & $\begin{array}{c}16.8 \\
8.3 \\
\end{array}$ & $\begin{array}{l}38.1 \\
36.9 \\
\end{array}$ & $\begin{array}{l}\text { Calculated intensities } \\
\text { Observed intensities }\end{array}$ \\
\hline $\begin{array}{l}\mathrm{Sr}_{2}(\mathrm{Mo})_{1}(\mathrm{Mg})_{I_{1} \mathrm{O}_{6}} \\
\mathrm{Sr}_{2} \mathrm{MgMoO}_{6}^{* *}\end{array}$ & $\begin{array}{l}29.1 \\
45.6\end{array}$ & $\begin{array}{l}100 \\
100\end{array}$ & $\begin{array}{l}15.2 \\
9.2\end{array}$ & $\begin{array}{l}13.5 \\
13.6\end{array}$ & - & $\begin{array}{l}\text { Calculated intensities } \\
\text { Observed intensities }\end{array}$ \\
\hline
\end{tabular}

Table 2. Cation distribution of the system $\mathrm{Sr}_{2} \mathrm{Mg}_{\mathrm{x}} \mathrm{Ni}_{1-\mathrm{x}} \mathrm{MoO}_{6}$ (I - W type site ; II - Ni type site [5])

*:Calculated cation distribution ; **: Nominal composition

A clear difference between the $\mathrm{Sr}_{2} \mathrm{Mg}_{\mathrm{x}} \mathrm{Zn}_{1-\mathrm{x}} \mathrm{MoO}_{6}$ and $\mathrm{Sr}_{2} \mathrm{Mg}_{\mathrm{x}} \mathrm{Ni}_{1-\mathrm{x}} \mathrm{MoO}_{6}$ type compounds could be observed: the zinc ions are placed on both type sites only in $\mathrm{Sr}_{2} \mathrm{ZnMOO}_{6}$, in all the remaining compounds of the corresponding series being placed in $\mathrm{W}$ sites. The zinc ions had preference for $\mathrm{W}$ type sites whose volume is smaller than that corresponding to Ni type sites. The nickel ions are randomly placed both on W type and Ni type sites.

\section{References}

[1] Brixner J., J. Phys. Chem. 64 (1960) 165-171.

[2] Cuprianov M. F. and Fesenko E. G., Kristallografija 7 (1962) 8*-10*.

[3] Palamaru M., Rusu I., Craus M. L. and Mares A., J. Serb. Chem. Soc. 58 (1993) 117-122.

[4] Palamaru M., Craus M. L. and Rusu I. J., Serb. Chem. Soc. 58 (1993) 1045-1049.

[5] Köhl, Z. Anorg. Allg. Chem, 401 (1973), 121-131.

[6] Taylor A. X-ray Metallography (J. Wiley \& Son, New-York, London, 1961), pp, 279. 